\title{
Morphometric Characterization of Parasite Varroa Sp. of Bee Apis Mellifera L. In Benin
}

Kelomey Eminsede Aude, Msc.

University of Abomey-Calavi, Laboratory of Biology and Molecular typing in Microbiology, Benin

\section{Paraiso Armand., PhD}

University of Parakou, Laboratory of Plant Protection, of pathology and parasitology of bees, Benin Azonwade Francois, Msc. University of Abomey-Calavi, Laboratory of Biology and Molecular typing in Microbiology, Benin

\section{Gbemavo Charlemagne, PhD}

University of Abomey-Calavi, Laboratory of Biomathematics and Forest Estimates, Benin

\section{Goergen Georg, PhD Tamo Manuelle, PhD}

National Biodiversity Centre, Benin, International Institute of Tropical Agriculture (IITA)

Baba-Moussa Lamine, PhD

University of Abomey-Calavi, Laboratory of Biology and Molecular typing in Microbiology, Benin

doi: 10.19044/esj.2016.v12n33p221 URL:http://dx.doi.org/10.19044/esj.2016.v12n33p221

\begin{abstract}
Varroa sp. is one of the most important pests of world of bees $A$. mellifera Linnaeus (Hymenoptera: Apidae). The aim of this study is to analyze the morphological variability of Varroa so as to identify the different morphotypes of $V$. destructor. The study was conducted in 24 localities and 24 municipalities located in three regions (North-East, North-West and the Centre) of Benin. One to two hives were randomly selected per locality for collecting samples. In total 46 Varroa were examined in this study. Analysis of variance components was used to determine the share of the variability of morphological characteristics of $V$. destructor based on localities and climatic zones. Numerical classification was performed to group the populations of V. destructor based on morphological descriptors. The results show that the variability of morphological descriptors of $V$. destructor is
\end{abstract}


usually larger at the community level than in climatic zones. In total four morphotypes of $V$. destructor are distinguished in Benin through the 4 variables used in the study.

Keywords: Varroa destructor, morphotype, Apis mellifera L., Benin

\section{Introduction}

The bee Apis mellifera L. is an important social insect, for his role in the pollination of crops and products generated in hives. A third of the human diet depends on plants pollinated by insects especially bees (Paraïso et al. 2011, Paraïso et al. 2013a, Akinwadé, 2013). For over a decade, weakening and colony losses due to diseases favored by environmental factors, chemical and biological are observed globally (Vidal-Naquet, 2011). The collapse of bee colonies is a phenomenon that currently affects all continents. Arthropods V. destructor, Acarapis woodi, Aethina tumida, Braula coeca; Galleria mellonella and Achroea grisella were identified as major pests of bees (Krauss and Page 1995; Finley et al. 1996; Wilson et al. 1997; Hunt, 1998; Paraïso et al. 2011; Paraïso et al. 2012 and Paraïso et al. 2013b). The mite $V$. sp. is the most important parasite of bees in Europe, America and Asia (Anderson and Trueman 2000). Its original host is $A$. cerana in which the latter causes almost no damage (Ball, 1994). A. cerana tolerate and he lives at his expense in the hive. The transition and adaptation of the parasite in the species A. mellifera (Anderson and Trueman 2000) sparked numerous damage observed today in this species. This is bloodsucking ectoparasites (Vidal-Naquet, 2008; De Jong, 1997). The low resistance of the bee parasite promotes its rapid spread (Peng et al. 1987, Le Conte, 2010), weakening and desertion of bee colonies following the transmission of many parasitic diseases (Ball, 1994). It is a mite that affects both the brood and the adult honey bees (Fries, 1993). The adult male has a whitish, spherical and measure $0.8 \mathrm{~mm}$ long by $0.7 \mathrm{~mm}$ wide. He lives within the capped brood while the female has a reddish brown color, $1.1 \mathrm{~mm}$ long and $1.6 \mathrm{~mm}$ wide.

The major problems losses of bee colonies due to $V$. destructor parasite were reported in Europe and the US by Wilson et al. (1997) and Sammataro et al. (2000). V. destructor is often identified late when it arrives in a region. It is a parasite very few experienced beekeepers. It was identified in the colonies of Benin by Paraïso et al. (2011). The aim of our study was to identify the species present in Benin and different morphotypes that exists. This study will enable a better understanding of this parasite. 


\section{Material and methods \\ Study area}

The study was conducted in Benin (114,763 $\left.\mathrm{km}^{2}\right)$, a country in West Africa situated between meridians $0{ }^{\circ} 40$ 'and $3{ }^{\circ} 45^{\prime}$ east longitude and parallels $06^{\circ} 15^{\prime}$ 'and $12^{\circ} 25^{\prime}$ north latitude. The Collines Department (Zone 1 ) is wholly owned by the Guinean Sudanese climate zone marked by two rainy seasons that cover the periods from April to July and October to November. It is a transition zone (between South and North) of 16,900 $\mathrm{km}^{2}$ extending after the plates of Abomey and Kétou until 9th parallel north. This area is fully occupied by leached tropical ferruginous soils or depleted (INRAB 1995). One also meets vertisols and waterlogged soils in the valleys of rivers and streams that cross the area. Zones 2 and 3 , being in the Sudanese agro-ecological area, are between the 9th and le10e parallel north and a little beyond.

They cover some of Atacora and Donga. North East (Zone 2) is characterized by a Sudanese climate with a rainfall from April to October and a season dry season from November to March. Northwest of Benin (Zone 3) essentially has a mountain climate and has slight variations from one locality to another. Zones 2 and 3 are mainly dominated by tropical ferruginous soils with highly variable agronomic characteristics. These soils fine clay-sandy texture. We also meet lateritic soils and waterlogged soils in these areas (INRAB, 1995).

Benin's population is estimated at 9,983,884 inhabitants with a density of 57 inhabitants / $\mathrm{km}^{2}$ (INSAE, 2013). The main activities of the local population are agriculture, livestock and fisheries. Some farmers in Benin associate beekeeping agriculture for a better performance given the role of bees in the pollination of crops. Nowadays, beekeeping of Benin is facing many problems including parasitic Varroa.

\section{Sampling and data collection}

The study was conducted in 22 communes in three areas of Benin: North-West, North-East and Central area. These areas were chosen based on criteria parasite infestation rate and availability of beekeeping equipment. By town one or two localities have chosen. In total 24 localities were selected for the study. In the study area, bee colonies were visited to collect samples of $V$. sp. Total twenty-eight bee colonies were sampled in 24 localities. About a hundred bees were collected in containers containing alcohol at $96^{\circ}$ and transported to the Plant Protection Laboratory of Parasitology and Pathology of bees located in Parakou for examination. Bee containers were stirred for a few minutes according to the method of Macedo et al. (2002) and the female mites were dislodged. The collected mites were then stored separately in Eppendorf tubes containing 96\% ethanol and were then stored 
at $4{ }^{\circ} \mathrm{C}$ for subsequent morphometric analyzes. Varroa samples were then transported to the laboratory of IITA Biodiversity Centre morphometric studies.

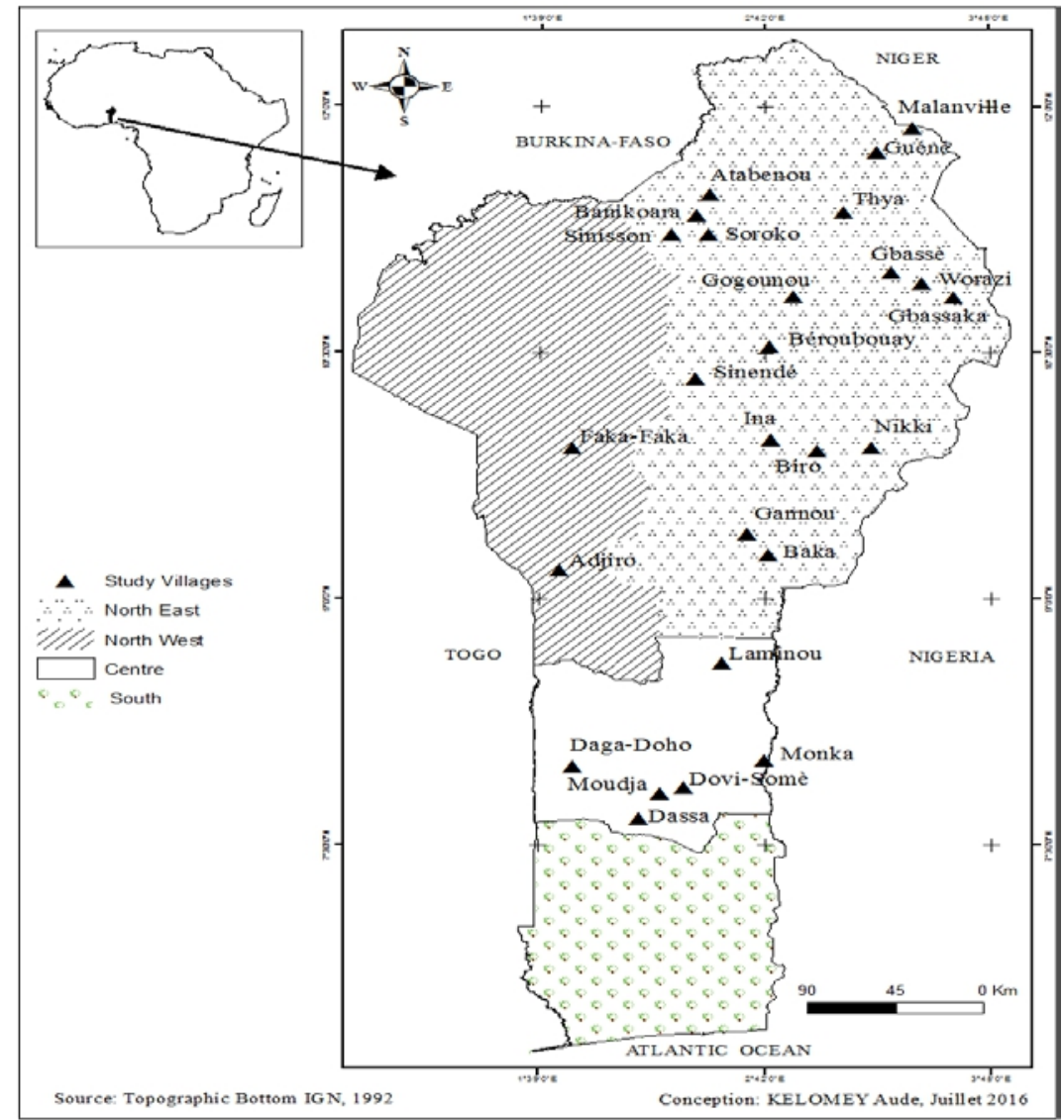

Figure 1. Study area and geographic distribution of visited villages.

\section{- $\quad$ Preparation of mites for microscopic examination}

A total of 46 mites were measured. The preparation method used is adapted from the Laboratory of Biodiversity of the International Institute Tropical Agriculture of Center of Dr. Georg GEORGEN. After extracting the specimens of the harvesting liquid, they were immersed in a clean bath of $70 \%$ ethanol in order to be cleaned. After this stage, the mites were put in $10 \% \mathrm{KOH}$ for 24 hours in order to lighten the inside of specimens for observation. Then, each specimen was cleaned under the microscope to remove the fatty mass located within the abdomen and which hinders observation. After this step, the specimens were transported in carbol Xylene for about 25 minutes for rinsing. Then, the specimens were transferred to a fuchsine solution for one hour for coloring. Finally, the specimens were placed in eye Glove for 25 min and were then mounted on microscope slides. 
After having spread the specimen on a slide with its ventral side upwards, 1 or 2 drops of Canada balsam are poured over the specimen and the whole is covered with a cover glass. The slides were labeled and were placed in a drier at 40' until complete drying of the balm which will turn yellow. Then the body length, width of the body, width of the anal shield and width of the genital shield were measured on each specimen.

\section{- $\quad$ Measurements of the length and width of the mite body}

Measurements of the length and width of the body of the mites were carried out using a microscope eyepiece adapted to a computer that is equipped with a $40 \mathrm{X}$ magnifying power micrometer measuring software.

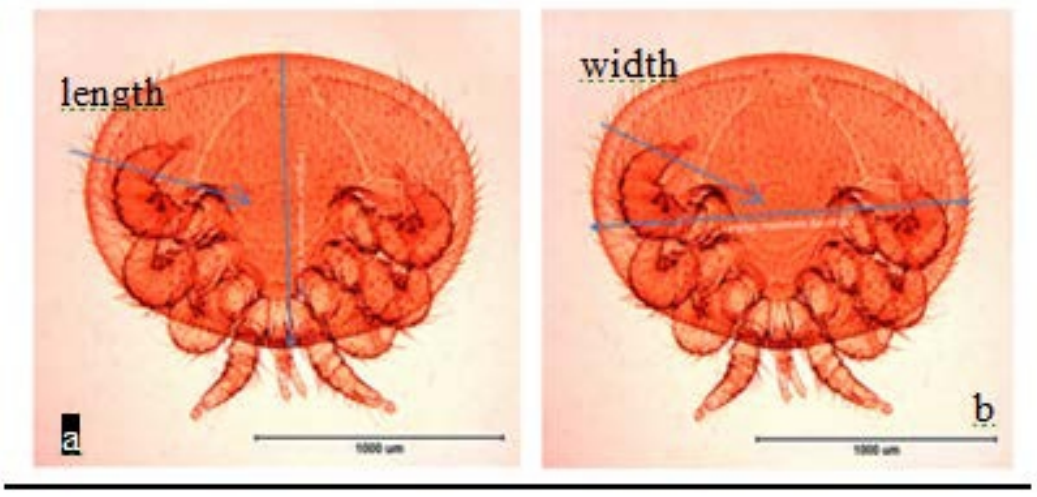

Figure 2: Measurements of length a) and width b) of Varroa.

- Measurements of the width of the anal and genital shields of the mite

Measurements of the width of anal and genital shields were taken using a microscope eyepiece adapted to a computer that is equipped with a micrometer measuring software with a $100 \mathrm{X}$ magnifying power.

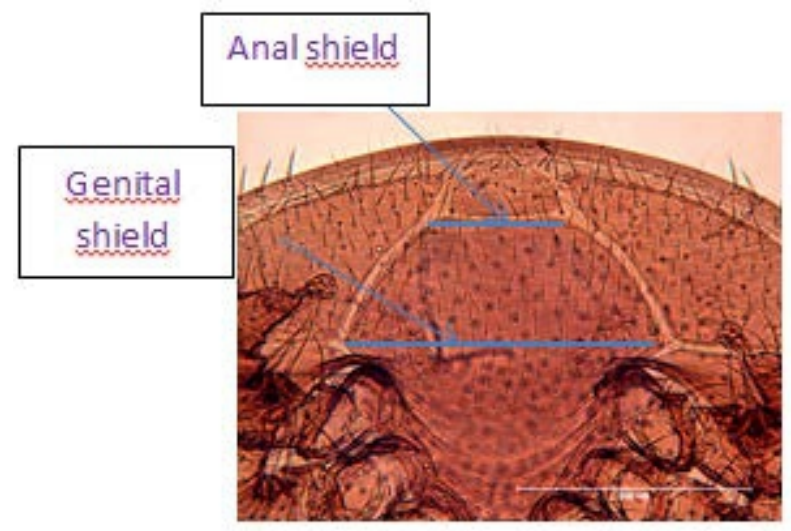

Figure 3: Measurement of the width of the anal and genital shields of Varroa. 


\section{Statistical analysis}

An analysis of variance components was performed on all the morphological descriptors of Varroa in the twenty-eight people to analyze the share of the overall variability due to localities and study areas. A numerical classification was performed on the adjusted morphological descriptors, which brought together the people. In total four morphological groups mite was identified. A selection of the most discriminating morphological descriptors morphological groups of Varroa was made from a discriminant analysis step performed on the row-column matrix consisting of the morphological groups and morphological descriptors. Then a canonical discriminant analysis was performed on morphological descriptors Varroa selected to evaluate their discriminating power. Morphological characterization of the different morphological groups was carried out on the basis of discriminating descriptors after a multivariate analysis of variance (ANOVA) conducted to compare the discriminating descriptors between morphological groups of Varroa. Data were log-transformed, in order to homogenize their variance before being subjected to ANOVA. Statistical analyzes were performed with the R3.2.0 software (R Development Core Team. 2012. http://www.Rproject.org/). Principal component analysis (ACP) was also carried out with sofware Minitab 14.

\section{Results}

\section{Variability of the morphological features of Varroa}

The analysis of the components of the variance performed on all morphological descriptors of the varroas studied reveals a variability of the morphological descriptors which is generally larger between localities than between the areas (Table 1).

Table 1: Results of analysis of the components of the variance on the morphological descriptors of Varroa

\begin{tabular}{ccccc}
\hline Components & Body length (BL) & $\begin{array}{c}\text { Body width } \\
\text { (BW) }\end{array}$ & $\begin{array}{c}\text { Width of genital } \\
\text { shield (WGS) }\end{array}$ & $\begin{array}{c}\text { Width of anal } \\
\text { shield (WAS) }\end{array}$ \\
\hline Zones & $(0)$ & $(0)$ & $(73.76)$ & $(0.00)$ \\
\cline { 2 - 5 } & 0 & 0 & 15,91 & 0 \\
\hline Localities & $(2022)$ & $(4083)$ & $(389.75)$ & $(94.14)$ \\
\cline { 2 - 5 } & 100 & 100 & 84,08 & 100 \\
\hline
\end{tabular}

\section{Classification, discriminating powers of descriptors and morphological characterization of Varroa}

The results of the rising hierarchical classification help to view with a height of information storage of 200 four homogeneous groups of localities (Figure 4). The total number of localities in the various groups is respectively $2 ; 14 ; 2$ and 10 for groups $1 ; 2 ; 3$ and 4 . 


\section{Cluster Dendrogram}

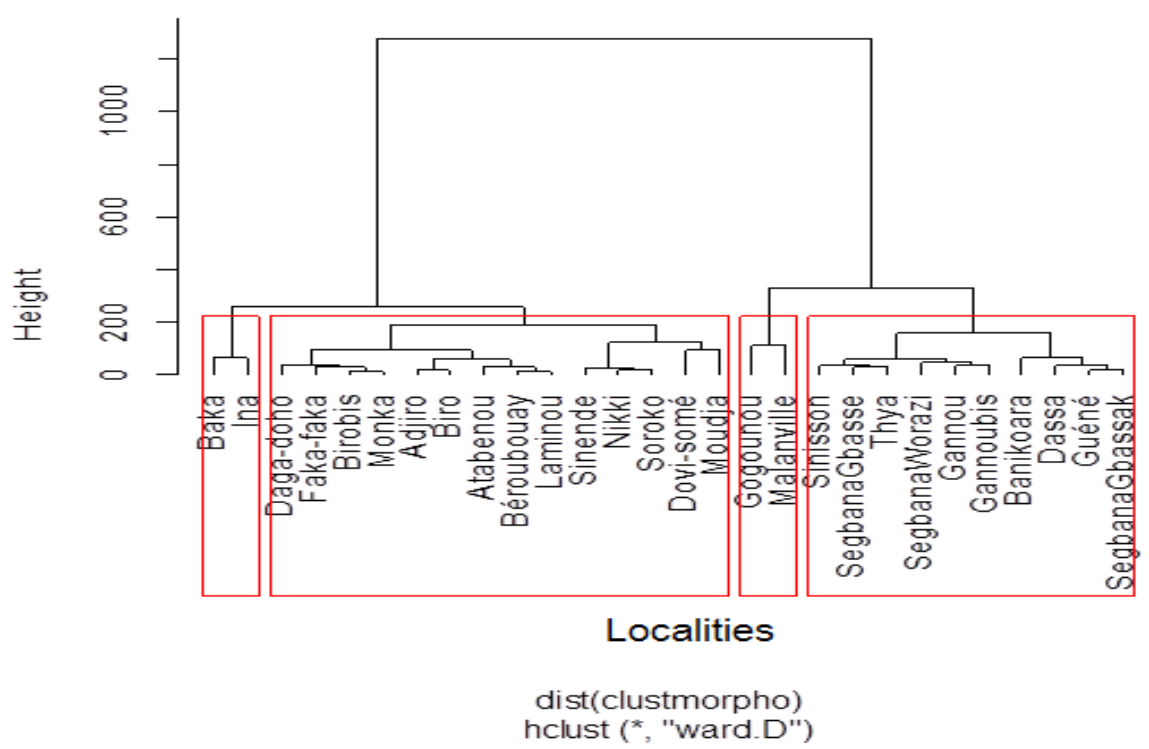

Figure 4: Dendrogram showing the grouping of varroas of localities according to their similarity

The results of the canonical discriminant analysis carried out to identify the characteristics of Varroa that help to discriminate the groups revealed that the first two canonical axes were generally significant ( $P$ $<0.05$ ) with $94.89 \%$ for the first axis and 5,02\% for the second axis. Wilks test showed a significant difference between the four groups of Varroa (Wilks' Lambda $=0.04 ; \mathrm{p}<0.05$ ). The analysis of correlations between each of the two axes and morphological descriptors made it possible to deduce that the four descriptors of Varroa showed a positive correlation with the first axis (Table 2).

Table 2: Correlation between the original variables and the two canonical axes

\begin{tabular}{ccc}
\hline Variables & Can1 & Can2 \\
\hline Maximum Body length & $\mathbf{0 . 8 7}$ & 0.31 \\
\hline Maximum Body width & $\mathbf{0 . 9 8}$ & 0.06 \\
\hline Width of genital shield & $\mathbf{0 . 8 5}$ & -0.11 \\
\hline Width of anal shield & $\mathbf{0 . 7 0}$ & $\mathbf{- 0 . 5 8}$
\end{tabular}

The second was negatively correlated with the width of the anal shield. Thus, the four descriptors used helped to recognize the varroas of the four groups. The joint schematization of the varroas identified by their group in the first factorial plane formed by the canonical axes 1 and 2 (Figures 5.a and 5b) showed that the first axis separated groups G1 and G2 from the other two groups of Varroa (G3 and G4). The four descriptors used 
allowed the recognition of varroas of groups G3 and G4. Indeed, the position of groups G3 and G4 on axis 1 suggested that the varroas of these groups were characterized by variable values.
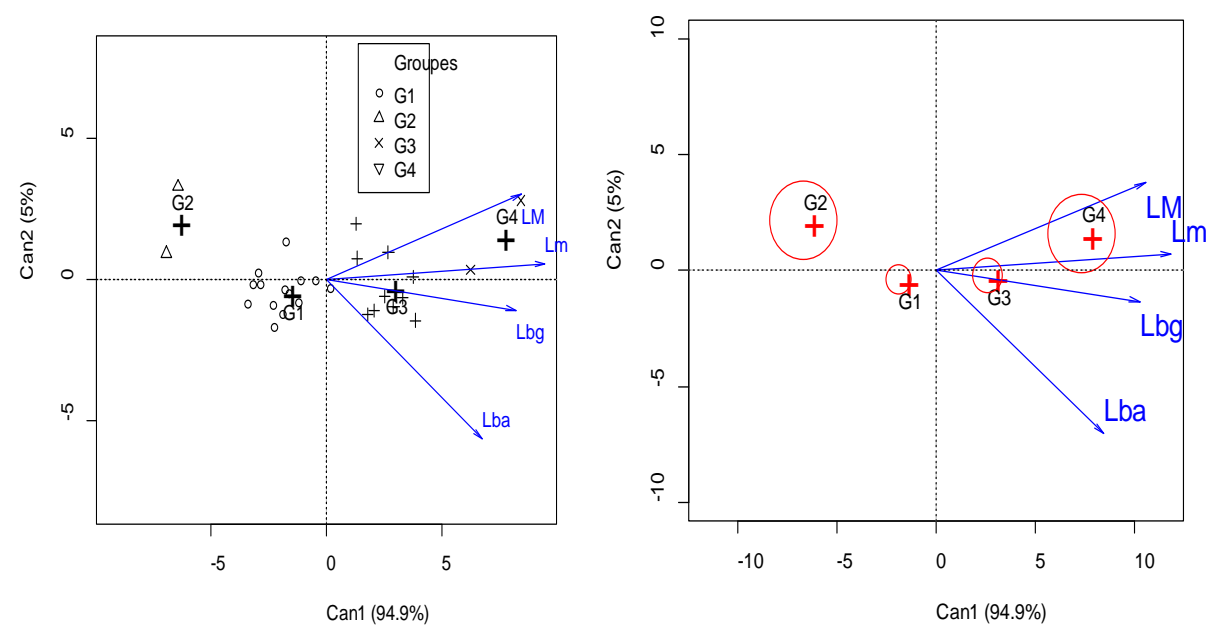

Figure 5. First factorial plane of the canonical discriminant analysis; a) joint schematization of mites and their characteristics; b) joint schematization of groups of Varroa and their characteristics.

Key: LM: Maximum length of the body; the: Maximum width of the body; lbg: Length of genital shield; lba: Width of the anal shield.

\section{Characteristics of groups identified}

The analysis of variance showed that it has a very highly significant difference $(\mathrm{p}<0.001$ ) between the four Varroa morphological groups regarding the four variables (Table 3).

Table 3: Quantitative description (mean \pm standard error) of measured variables associated with different groups of Varroa.

\begin{tabular}{|c|c|c|c|c|c|c|c|c|c|}
\hline \multirow[b]{2}{*}{ Variables } & \multicolumn{2}{|c|}{ Group1 } & \multicolumn{2}{|c|}{ Group 2} & \multicolumn{2}{|c|}{ Group 3} & \multicolumn{2}{|c|}{ Group 4} & \multirow[t]{2}{*}{ Prob } \\
\hline & $\mathrm{m}$ & se & $\mathrm{m}$ & se & M & se & $\mathrm{m}$ & se & \\
\hline $\begin{array}{l}\text { Maximum } \\
\text { Body length }\end{array}$ & 1064.2 & 8.20 & 1036.6 & 21.71 & 1135.1 & 9.71 & 1224.5 & 21.71 & $* * * 0,000$ \\
\hline $\begin{array}{l}\text { Maximum } \\
\text { Body width }\end{array}$ & 1589.9 & 6.68 & 1598.1 & 17.68 & 1681.4 & 7.90 & 1790.3 & 17.68 & $* * * 0,000$ \\
\hline $\begin{array}{l}\text { Width of } \\
\text { genital } \\
\text { shield }\end{array}$ & 663.4 & 4.56 & 622.3 & 12.07 & 692.0 & 5.40 & 723.1 & 12.07 & $* * * 0,000$ \\
\hline $\begin{array}{c}\text { With of anal } \\
\text { shield }\end{array}$ & 244.6 & 2.19 & 219.2 & 5.80 & 255.1 & 2.59 & 254.9 & 5.80 & $* * * 0,000$ \\
\hline
\end{tabular}


The principal component analysis grouped the 28 localities into various components with the first three axes explaining $97.3 \%$ of the total variation (Table 4). Principal component 1 (PC1) negatively associated with maximum body length and width accounted for $74.7 \%$ of the total variation (Table 4). PC2 negatively associated with width of genital shield accounted for $14.1 \%$ of the total variability (Table 4 ). The maximum body length and width of genital shield are those mostly correlated to the third axis accounting for $8.5 \%$.

Table 4: Eigen vectors and values for the four principal component areas

\begin{tabular}{ccccc}
\hline & PC1 & PC2 & PC 3 & PC 4 \\
\hline Eigenvalue & 2,9873 & 0,203 & 0,3388 & 0,1079 \\
Proportion\% & 0,747 & 0,141 & 0,085 & 0,027 \\
Cumulative\% & 0,747 & 0,888 & 0,973 & 1,000 \\
\hline Variables & & & & \\
\hline LM & $-0,508$ & 0,203 & 0,748 & \\
Lm & $-0,554$ & 0,125 & 0,002 & \\
Lbg & $-0,499$ & 0,414 & $-0,650$ & \\
Lba & $-0,431$ & $-0,879$ & $-0,133$ & \\
\hline
\end{tabular}

Groups formed in the ACP are identical to those of the canonical analysis (Figure 5).

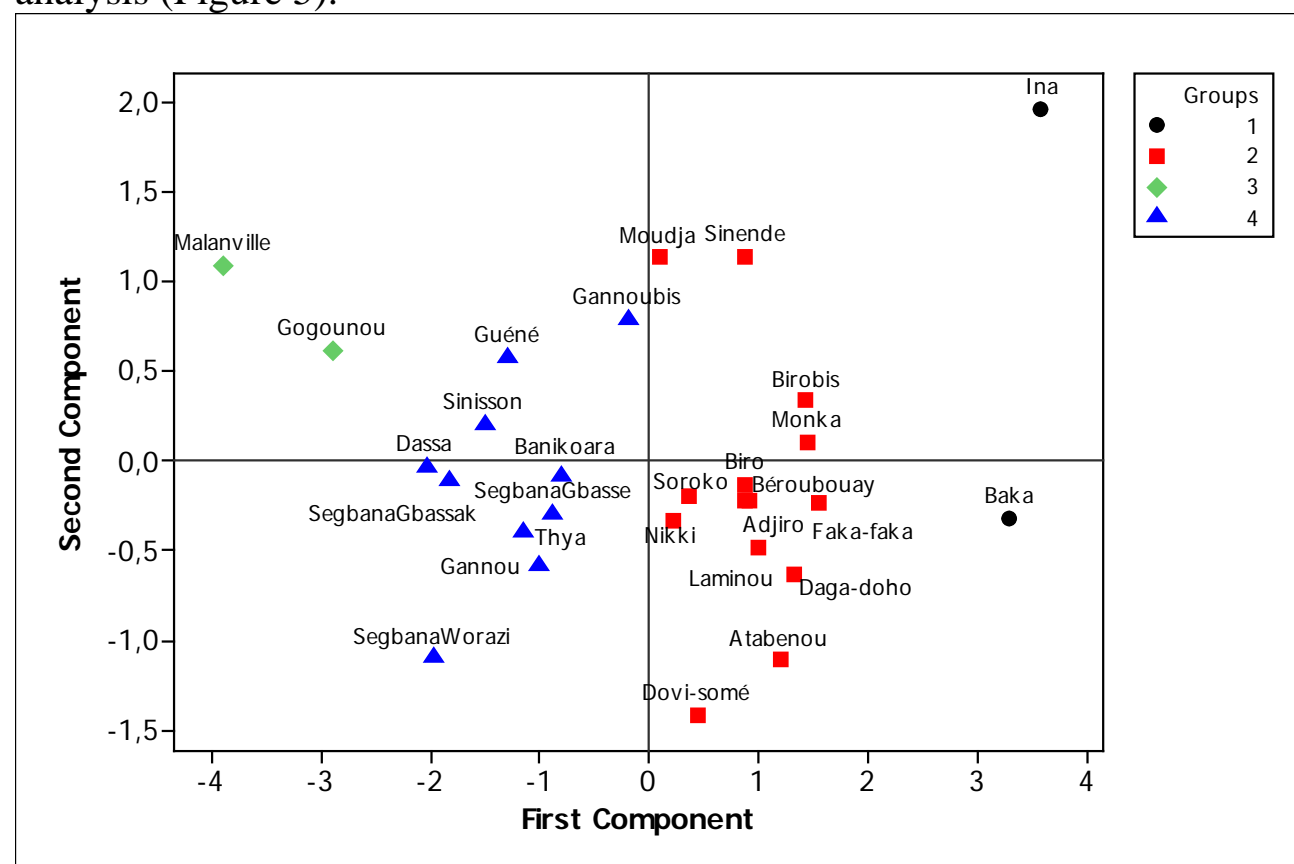

Figure 5: Principal component analysis showing the different grouping of the accessions of Varroa sp.

\section{Discussion}

The objective of our study was to identify the subspecies of Varroa 
and the different morphotypes of Varroa that exist in colonies of bees in Benin. This study identified the morphotypes of Varroa by taking morphometric measurements.

Measurements of body parameters (length and width) of the analyzed Varroa compared to Anderson and Trueman data (2000), Zhang (2000) and Boudagga et al. (2003) showed that there is a similarity between the averages for measurements of samples of Varroa destructor in these countries (Table 5). Morphometric characters of specimens studied corresponded to that of Varroa destructor and not the Varroa. The samples have a high phenotypic consistency and were larger in length and width of the body that Varroa jacbsoni confirming that all the mites specimens examined belong to the species called Varroa destructor.

The infestation of the parasite Varroa observed in all sampled hives indicates that the mite Varroa has invaded all the hives of Benin, which corroborates studies Paraïso et al. (2011). The data of De Jong (1997) show that the epidemic of Varroa is a global problem and that the mite Varroa has a strong virulence in the colonies of Apis mellifera L. The viral infection can cause physical abnormalities in adults such as distorted wings, reduction in the ability to fly and longevity of workers (Marcangeli, 1992, Bakonyi et al. 2002; Chen et al. 2004; Tentcheva et al. 2006; Cornellisen et al. 2011).

The results showed a morphological variability of the descriptors which is more significant between the localities than in climatic zones. This shows that the variation within population (in climate zones) was more significant for these characters than variability between populations. The very low variability of descriptors observed between the populations of the three zones is related to genotypic factors; indeed, the size (length and width) of mites varies according to the species of bees present in the zone where the sample collection is performed. Indeed, the subspecies of Varroa are morphologically distinct and have specific differences in their geographical distribution (Anderson and Trueman 2000). The species Apis mellifera L. is infested only by the subspecies Varroa destructor (Muñoz et al.2008). Varroa destructor is found in Europe, Africa and the United States while Varroa jacobsoniis is found in Asia (Solignac et al.2002, 2005; Anderson and Trueman 2000). Similarly, according to the work of Delfinado-Baker (1989), the parasite Varroa has an average length of 1037.52 microns which is different from the average length of the parasite Varroa destructor which is $1106.31 \mu \mathrm{m}$. The average length and width of the body of parasites in the study area were 1115.1 and 1639.9 microns. According to the data of Akinwadé (2013), Boudaga et al. (2003), Zhang (2000) and Anderson and Trueman (2000) (Table 4), the measured mites belong to the subspecies Varroa destructor of Benin. The samples analyzed presented a high phenotypic consistency and were larger in the body length and width than 
Varroa jacbsoni. However, the average values of the measurements of length and width of the body of the parasites in groups 1 and 2 consisting of samples from the Centre and Northeast are smaller than those of the literature (Anderson and Trueman, 2000). These results corroborate those of Paraïso et al. (2011) who obtained average values of $1 \mathrm{~mm}$ in length to 1.75 $\mathrm{mm}$ in width for measurements of the samples of Varroa in Benin and justified this result by the adaptations of $V$. destructor to the smallest subspecies $A$. m.adansonii compared to other bees of bigger size.

The results of the rising hierarchical classification and Wilks test showed that varroas of Benin fall into four statistically distinct groups. These results indicate heterogeneity in the analyzed populations of Varroa and show the presence of four morphotypes of Varroa destructor in Benin. Moreover, all the four morphometric characters used in this study have a significant discriminating power.

Table 5: Measures (in $\mu \mathrm{m}$ ) of the length and width of the body (Mean \pm se) of the females

Varroa of Benin compared to the biometry of Varroa jacobsoni and Varroa destructor referenced by Akinwadé (2013), Anderson and Trueman (2000), Zhang (2000) and Boudaga et al. (2003).

\begin{tabular}{c|c|c|c}
\hline \multicolumn{2}{c}{$\begin{array}{c}\text { Body length } \\
\mathrm{m} \pm \mathrm{se}\end{array}$} & $\begin{array}{c}\text { Body width } \\
\mathrm{m} \pm \mathrm{se}\end{array}$ & $\begin{array}{c}\text { No. of specimens } \\
\text { examined }\end{array}$ \\
\hline Parasites Varroa of Bénin & $\begin{array}{c}1115.1 \pm \\
15.33\end{array}$ & $\begin{array}{c}1639.9 \pm \\
12.48\end{array}$ & 46 \\
\hline $\begin{array}{c}\text { Varroa destructor of Kosere, } \\
\text { Ogun State, Nigeria } \\
\text { (Akinwadé 2013) }\end{array}$ & $\begin{array}{c}1177.96 \pm \\
7.09\end{array}$ & $\begin{array}{c}1718.12 \pm \\
1.4\end{array}$ & 20 \\
\hline $\begin{array}{c}\text { Varroa destructor (Anderson } \\
\text { et Trueman 2000) }\end{array}$ & $1167.3 \pm 26.8$ & $\begin{array}{c}1708.9 \pm \\
41.2\end{array}$ & 42 \\
\hline $\begin{array}{c}\text { Varroa jacobsoni (Anderson } \\
\text { et Trueman 2000) }\end{array}$ & $1063.0 \pm 26.4$ & $1506.8 \pm$ & 73 \\
\hline Varroa destructor (Zhang \\
2000) & $1159.0 \pm 21.6$ & $1700.0 \pm$ & 5 \\
\hline Varroa destructor (Boudagga \\
2003) & $1204.9 \pm 40.1$ & 1738.5 & 20 \\
\hline Varroa destructor (Boudagga, \\
2003)
\end{tabular}

\section{Conclusion}

The parasite $V$. destructor causes significant economic losses in the beekeeping sector. Our results showed that the mite of Benin belongs to the subspecies Varroa destructor and fall into four statistically distinct morphotypes. We suggest that molecular studies should be conducted on varroas from Benin to determine the haplotype of Varroa present in Benin and the genetic diversity within morphotypes. 


\section{Acknowledgments}

We thank the World Bank through the Agricultural Production Project in West Africa (WAAPP) for financially supporting us to conduct this study. We are grateful to The International Foundation for Science (IFS) for its financial support as well. We thank all beekeepers who allowed us to collect samples in their apiaries. We thank the Plant Protection Laboratory of Pathology and Parasitology of Bees (LAPPAB) for the collection and conservation of different samples. We also thank the National Biodiversity Centre of the International Institute of Tropical Agriculture (IITA) for the various measurements.

\section{References:}

1. Anderson, D.L. (2000). Variation in the parasitic mite Varroa jacobsoni. Apidologie, 31: 281-292.

2. Anderson, D.L. \& Trueman, J.W.H. (2000). Varroa jacobsoniis more than one species. Experimental and Applied Acarology, 24: 165-189.

3. Akinwande, K. L., Badejo, M. A. \& Ogbogu, S. S. (2013). Morphometrics and parasitic load of Varroa mites (Acari: Varroidae) on colonies of Apis mellifera adansonii( Hymenoptera apidae) in south western Nigeria. Acarina 21 (1): 17-26.

4. Bakonyi, T., Farkas, R., Szendroi, A., Dobos-Kovacs, M., \& Rusvai M. (2002). Detection of acute bee paralysis virus by RT-PCR in honey bee and Varroa destructor field samples: rapid screening of representative Hungarian apiaries. Apidologie 33: 63-74.

5. Ball, B.V. 1994. Host-parasite-pathogen interactions. In: A. Matheson (Ed.). New perspective on Varroa. IBRA, Cardiff, U.K., pp. 5-10.

6. Balogoun, I., Saidou, A., Ahoton, E. L., Amadji, G. L., Ahohuendo, C. B., Adebo, J. B., Babatoundé, S., Chougourou, D., Adoukonou, S. H. \& Ahanchédé, A. (2014). Caractérisation des systèmes de production à base d'anacardier dans les principales zones de culture au Bénin. Agronomie africaine. 26 (1): -9-22.

7. Boot, W.J., Tan, N.O., Dien, P.C., Huan, L.V., Dung, N.V., Long, L.T. \& Beetsma J. (1997). Reproductive success of Varroa jacobsoni brood of its original host, Apis cerana, in comparison to that of its new host, Apis mellifera (Hymenoptera: Apidae). Bulletin of Entomological Research, 87: 119-126.

8. Boudagga, H., Barbouche, N., Laarif, A., \& Hamonda, M.H.D. (2003). Morphological identification of the Varroa species (Acari:Varroidae) colonizing Tunisia apiaries. Systematic Applied Acarology, 8: 97-100. 
9. Chen, Y. Pettis, J. S., Evans, J. D., Kramer, M., \& Feldlaufer, M. F. (2004). Transmission of Kashmir bee virus by the ectoparasitic mite Varroa destructor. Apidologie 35: 441-448.

10. Cornellissen, B., Paraïso, A., \& Van Hoof, R. (2011). Bee diseases new to sub-Saharan Africa found in Benin. Poster presented at the International Beekeeping Congress. Apimondia. Buenos Ares. Argentina.

11. Dagnelie, P. (1986). Théorie et méthodes statistiques. Applications agronomiques. Vol 2. Les presses agronomiques de Gembloux. A.S.B.L. (Belgique). $463 \mathrm{p}$.

12. De Jong, D. (1997). Mites: Varroa and other parasites of brood. In: R.A. Morse, K. Flottum (Eds.). Honey bee pests, predators, and diseases, 3rd edition. Ithaca Cornell University Press, pp. 279-328.

13. Finley, J., Camazine, S. and Frazier, M. (1996). The epidemic of honey bee colony losses during the 1995-1996 season. American Bee Journal, 136 (11): 805-808.

14. Fries, I.G. (1993).Varroa biology: a brief review. In: A. Mathelson (Ed.). Living with Varroa. IBRA, Cardiff, UK, pp. 3-7.

15. Hunt, G.J. (1998). The war against Varroa: how are we doing? American Bee Journal, 138 (5): 372-374.

16. Institut National des Recherches Agricoles du Bénin. (1995). Fiches techniques sur les sols et les essences forestières. INRAB Cotonou Bénin, édition 1995. 68 p.

17. Institut National de la Statistique et de l'Analyse Économique (INSAE), (2013). Rapport. Résultats provisoires du Recensement Général de la Population et d’Habitat 4. Rapport d'étude. Cotonou : INSAE. www.insae-bj.org,

18. Kraus, B. \& Page, R.E. (1995). Effect of Varroa jacobsoni (Mesostigmata: Varroidae) on feral Apis mellifera (Hymenoptera: Apidae). California. Environ. Entomol., 24 (6): 1473-1480.

19. Le Conte, Y., Ellis, M. \& Ritter, W. (2010). Varroa mites and Honey bee health: can Varroa explain part of the colony losses? Apidologie, 41: 353-363.

20. Macedo, P.A., Wu, J. \& Ellis, M.D. (2002). Detection and assessing Varroa mites infestations by using powdered sugar to dislodge mites. American Bee Journal, 140 - 906.

21. Marcangeli, J.A., Eguaras, M.J., \& Fernandez, N.A. (1992). Reproduction of Varroa jacobsoni (Acari: Mesostigmata: Varroidae) in temperate climates of Argentina. Apidologie, 23: 57-60.

22. Oudemanns, A.C. (1904). On a new genus and species of parasitic Acari. Notes Leyden Mus., 24: 216-222. 
23. Paraïso, A., Cornellissen, B., \& Viniwanou, N. (2011).Varroa destructor infestation of honey bee (Apis mellifera adansonii) colonies in Benin. Journal of Apicultural Research 50 (4): 321-322.

24. Paraïso, A., Agassounon, M., Daouda, Iz H., Amevoin, K., \& Glitho, I. A. (2012). First Record of Braula coeca Nitzsch (Diptera: Braulidae), parasite of Apis mellifera adansonnii in Benin. International Journal of Science and Advanced Technology. Vol. 2 No 12 (ISSN 2221-8386).

25. Paraïso, A., Olodo, G. P., Tokoudagba, S., Ayeleroun, R., Yegbemey, R. N., \& Sanni, A. (2013a). Déterminants et contraintes de la production du miel dans le Nord-Ouest du Bénin: Cas des communes de Natitingou et de Tanguiéta. J. Rech. Sci. Univ. Lomé (Togo), 2013, Série A, 14 (1): 69-82.

26. Paraïso, A., Tamou, Tabe, S., Ayeleroun, R., Abiola, W., \& Adjoha, B. (2013b). Parasites and predators of honey bee Apis mellifera adansonii in Benin. Poster presented at the XXXXIIIth International Congress of APIMONDIA. Kiev, Ukrainia. 29 Sept - 04 October 2013.

27. Peng, Y.S., Fang, Y., Xu, S. \& Ge, L. (1987). The resistance mechanism of the Asian honey bee, Apis cerana Fabr, to an ectoparasitic mite Varroa jacobsoni Oudemans. Journal of Invertebrate Pathology, 49: 54-60.

28. Root, A.I. (1990). The ABC and XYZ of Bee Culture. 40th ed. Revised by E.R. Root, H.H. Root, and J.A. Root. A.I. Root Company: Medina, Ohio.

29. Sammataro, D., Gerson, U., \& Needham, G. (2000). Parasitic mites of honey bees: life history, implications, and impact. Annual Review of Entomology, 45: 519-548.

30. Tentcheva, D., Gauthier, L., Bagny L, \& Flevet J. (2006). Comparative analysis of deformed wing virus (DWV) RNA in Apis mellifera and Varroa destructor. Apidologie 36: 41-50.

31. Wilson, W.T., Pettis, J.S., Henderson, C.E., \& Morse, R.A. (1997). Tracheal mites. In: R.A. Morse and K. Flottum (Eds.). Honey bee pests, predators, and diseases, 3rd edition. Ithaca: Cornell University Press, pp. 253-278.

32. Zhang, Z.Q. (2000). Notes on Varroa destructor (Acari: Varroidae) parasitic on honey bees in New Zealand. Syst. Appl. Acarology, Special Publication, 5: 9-14. 